\title{
Tagging juvenile European perch (Perca fluviatilis L.) with passive integrated transponders (PIT) - impact on growth, condition, and physiological indexes
}

\author{
Zdzisław Zakęś, Maciej Rożyński, Elżbieta Ziomek, Krystyna Demska-Zakęś
}

Received - 05 May 2017/Accepted - 21 September 2017. Published online: 30 September 2017; $\odot$ Inland Fisheries Institute in Olsztyn, Poland Citation: Zakęś Z., Rożyński M., Ziomek E., Demska-Zakęś K. 2017 - Tagging juvenile European perch (Perca fluviatilis L.) with passive integrated transponders (PIT) - impact on growth, condition, and physiological indexes - Arch. Pol. Fish. 25: 201-207.

\begin{abstract}
The aim of the study was to determine the impact of intramuscular tagging with passive integrated transponders (PIT tags) on the basic condition and hematological and biochemical indexes of the blood plasma of juvenile European perch (initial body weight of approximately $80 \mathrm{~g}$ ). Throughout the observation period, i.e., for 42 days following PIT implantation, the procedure was not noted to have had a negative impact on fish growth, condition, or feed conversion ratio. The blood plasma biochemical indicators analyzed did not differ statistically significantly between the fish tagged with PIT and the untagged control group. No significant impact from this procedure was noted in the hematological indexes tested. Only with regard to the mean corpuscular hemoglobin $(\mathrm{MCH})$ parameter was the value significantly lower in the fish tagged with PIT than in the control group $(\mathrm{P} \leq 0.05)$. The difference determined was 1.40 pg (28.78 vs. 30.18). The MCH level in the fish tagged with PIT most probably was within the norm for this species. High tag retention (100\%) and the lack of any significant impact on condition or hematological and biochemical indexes (with the exception of $\mathrm{MCH}$ ) permits recommending this tagging method for use in juvenile perch.
\end{abstract}

\section{Z. Zakę̧s [ఏ]], M. Rożyński}

Department of Aquaculture, Stanisław Sakowicz Inland Fisheries Institute in Olsztyn

ul. Oczapowskiego 10, 10-719 Olsztyn, Poland

e-mail: zakes@infish.com.pl; tel. +48 895240171;

fax +48895240505

\section{E. Ziomek, K. Demska-Zakęś}

Department of Ichthyology, Faculty of Environmental Sciences,

University of Warmia and Mazury in Olsztyn, Poland
Keywords: physiology, perch, PIT, tag retention, rearing indexes, tagging

Passive integrated transponders (PIT) have been used in ichthyological studies since the 1980s (Prentice et al. 1990). Although this method was developed for fish, it has also found applications in studies of mammals (Brady et al. 2000), birds (Ballard et al. 2001), reptiles (Mills et al. 1995), amphibians (Perret and Joly 2002), and even invertebrates (Pengilly and Watson 1994). The popularity of PIT stems from its virtually unlimited lifespan, simple application, huge number of possible individual code combinations, and relatively small size (Skalski et al. 2009).

PIT tags are also characterized by high retention rates and slight or even no impact on tagged organisms (Baras et al. 2000, Navarro et al. 2006, Hopko et al. 2010, Zakęś and Hopko 2013). To date, the reactions of fish to the PIT tagging procedure have been analyzed in terms of growth, condition, mortality, and feeding efficiency. Studies of hematological and biochemical parameters can supply more complete data on fish condition and health (Folmar 1993). In addition to many important life functions, such as transport and hemostasis, the blood also ensures communication among specific tissues and organs. This is why disruptions in an organism can impact the values of different hematological or blood biochemical indexes. In 
addition to assessing fish condition and health status, analyses of these parameters permits monitoring, inter alia, the effects of stressors of various origin (Çelik 2004, Brinn et al. 2012, Akrami et al. 2013). Hematological parameters, for example, the number of erythrocytes, are also indicators of fish strategies for adapting physiologically to environmental changes (Val et al. 1992). This type of information can be helpful in work associated with fish well-being in its broadest sense (Zutshi et al. 2010).

The aim of this study was to determine the impact tagging juvenile European perch, Perca fluviatilis L. with PIT tags has on their condition and physiological status, i.e., their hematological and biochemical blood plasma indexes.

The study material was obtained by collecting fertilized $P$. fluviatilis eggs from spawning grounds during the natural spawning period in early April (Lake Dgał Wielki, northern Poland). The eggs were transported to an earthen pond with a surface area of approximately 0.2 ha. The eggs were incubated and hatched in the pond, where the larvae and juvenile stages were reared on natural feed. In mid-June, when the European perch had attained body weights of approximately $0.2 \mathrm{~g}$, they were caught and transferred to a recirculating aquaculture system (RAS, 2 tanks with a volume of $2 \mathrm{~m}^{3}$ ), where they were trained to consume Nutra formulated feed (Nutreco, Trouvit, France) (Policar et al. 2015). After the fish had reached a body weight of approximately $10 \mathrm{~g}$, the fed was changed to T-T Nutra MP (Skretting, Holland) with a chemical composition of: protein - $50 \%$; crude fat - $20 \%$; fiber $-2.4 \%$; ash $-8 \%$. The fish were fed with an automatic band feeder (Fischtechnik GmbH, Nienburg, Germany) for $18 \mathrm{~h} \mathrm{~d}^{-1}$. The environmental conditions in the RAS during rearing were as follows: temperature $-19.7 \pm$ $0.1^{\circ} \mathrm{C}$; $\mathrm{pH}$ range $-7.80-8.01$; oxygenation at rearing tank outflow $\geq 7.3 \mathrm{mg} \mathrm{O}_{2} \mathrm{l}^{-1}$; total ammonia nitrogen $\left(\mathrm{TAN}=\mathrm{NH}_{4}{ }^{+}-\mathrm{N}+\mathrm{NH}_{3}-\mathrm{N}\right)$ measured at the outflow of the rearing tanks $\leq 0.2 \mathrm{mg} \mathrm{TAN}^{-1}$, nitrites $-\left(\mathrm{NO}_{2}-\mathrm{N}\right)$ $\leq 0.1 \mathrm{mg} \mathrm{NO}-\mathrm{N} \mathrm{l}^{-1}$. After the perch had reached a body weight of approximately $70 \mathrm{~g}$ and a body length SL of approximately $16 \mathrm{~cm}$, they were anesthetized in an aqueous solution of etomidate $-1.5 \mathrm{ml} \mathrm{l}^{-1}$ (Propiscin, IFI Olsztyn, Poland), tagged with passive integrated transponders (PIT; Fish Eagle, Lechlade, Great Britain) (material - bioglass; length - $12.00 \pm 0.40 \mathrm{~mm}$; diameter - $2.12 \pm 0.07 \mathrm{~mm}$; weight $-93 \mathrm{mg}$ ). The PIT were injected through a needle (internal diameter $2.86 \mathrm{~mm}$ ) into the muscle underlying the first dorsal fin (Hopko and Zakęś 2010) (Fig. 1). Thirty-six individuals were tagged and then stocked into six rearing tanks with volumes of $0.2 \mathrm{~m}^{3}$ each (6 fish per tank). The tagging procedure for the experimental group (PIT group) was repeated with individuals from the control group, with the exception of PIT tagging (group C), and they were also stocked into six rearing tanks (six individuals in each tank). The mean fish biomass was approximately $2.32 \mathrm{~kg} \mathrm{~m}^{-3} \operatorname{tank}^{-1}$.

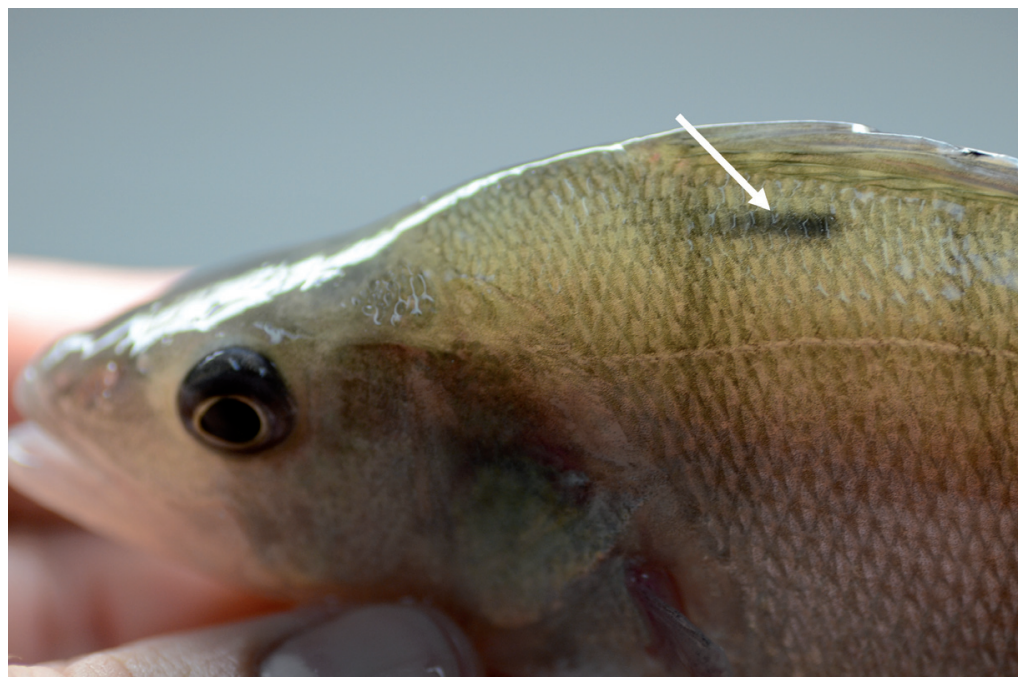

Figure. 1. PIT tag in the muscle of a perch (arrow).

The experiment ran for six weeks. Measurements of water temperature $\left( \pm 0.1^{\circ} \mathrm{C}\right)$ and oxygen concentration $\left( \pm 0.01 \mathrm{mg} \mathrm{O}_{2} \mathrm{l}^{-1}\right)$ at the rearing tank inflows and outflows were taken daily, while those of TAN $( \pm 0.01 \mathrm{mg}$ TAN $\left.~^{-1}\right), \mathrm{NO}_{2}-\mathrm{N}\left( \pm 0.01 \mathrm{mg} \mathrm{NO} \mathrm{NO}_{2}-\mathrm{N} \mathrm{l}^{-1}\right)$, and $\mathrm{pH}( \pm$ 0.01 ) were measured at the tank outflows every seven days. The mean water temperature was $21.0 \pm 0.1^{\circ} \mathrm{C}$. Oxygen concentration at the tank outflows did not fall below $7.40 \mathrm{mg} \mathrm{O}_{2} \mathrm{l}^{-1}$ (saturation 83.7\%). Oxygen levels at the inflow were maintained within a range of $90-98 \%$ 
saturation. TAN and $\mathrm{NO}_{2}-\mathrm{N}$ concentrations at the outflows did not exceed $0.08 \mathrm{mg} \mathrm{TAN}^{-1}$ and $0.016 \mathrm{mg}$ $\mathrm{NO}_{2}-\mathrm{N} \mathrm{l}^{-1}$. The water $\mathrm{pH}$ was within the range of 7.74-7.99. The fish were fed the formulated feed Bronze $3 \mathrm{~mm}$ (AllerAqua, Denmark) with a proximate composition of: protein $-45 \%$; crude fat $-15 \%$; carbohydrates $-24 \%$; fiber - $3 \%$; ash - $7 \%$; digestible energy $-17.6 \mathrm{MJ} \mathrm{kg}^{-1}$. The feed was delivered by an automatic band feeder (Fischtechnik GmbH, Nienburg, Germany) for $18 \mathrm{~h} \mathrm{~d}^{-1}$ (09:00-03:00). The feed ration was determined every seven days at $1.5 \%$ of the fish biomass.

Individual fish measurements (body weight (BW \pm $0.01 \mathrm{~g})$, standard length $(\mathrm{SL} \pm 0.1 \mathrm{~cm})$ ) were taken every week (day 0 (d0), d7, d14, d21, d28, d35, d42) (Table 1). The data collected permitted calculating the values of the following indexes: daily growth rate, DGR $\left(\mathrm{g} \mathrm{d}^{-1}\right)=\left(\mathrm{BW}_{2}-\mathrm{BW}_{1}\right) \times \mathrm{t}^{-1}$; specific growth rate, SGR $\left(\% \mathrm{~d}^{-1}\right)=100 \times\left(\ln \mathrm{BW}_{2}-\ln \mathrm{BW}_{1}\right) \times \mathrm{t}^{-1} ;$ Fulton's condition coefficient, $\mathrm{F}=100 \times \mathrm{BW} \times \mathrm{SL}^{-3}$; feed conversion ratio, $\mathrm{FCR}=\mathrm{TFS} \times(\mathrm{FB}-\mathrm{IB})^{-1}$; where: $\mathrm{BW}_{1}-$ initial fish body weight (g), $\mathrm{BW}_{2}$ - final fish body weight $(\mathrm{g}), \mathrm{t}-$ rearing time (days), SL - fish body length $(\mathrm{cm}), \mathrm{FB}$ - final stock biomass (g), IB - initial stock biomass (g), TFS - total feed supply (g). Additionally, the tanks were monitored daily for shed tags and dead fish.

After the conclusion of the experiment (d42), about $1 \mathrm{ml}$ of blood was drawn directly from the caudal vein of each individual using a heparinized syringe (Smiths Medical International ASD, Inc., St. Paul, Minnesota, USA). The samples were used to determine the hematological indexes of white blood cells (WBC), red blood cells (RBC), hemoglobin (HGB), hematocrit (HCT), platelet count (PLT), and to calculate the values of the red blood cell indexes of mean corpuscular volume (MCV), mean corpuscular hemoglobin (MCH), and mean corpuscular hemoglobin concentration (MCHC). After centrifuging the samples at $1500 \times \mathrm{g}$ for $3 \mathrm{~min}$ (Fresco 17, Thermo Scientific, Waltham, USA), the following chemical indexes were determined in the material obtained: creatinine (CREA); total protein (TP); total bilirubin (BIL-T); alanine transaminase (ALT); alkaline phosphatase (ALP); calcium (Ca); albumin (ALB); globulin (GLB); glucose (GLU); magnesium (Mg); ammonia $\left(\mathrm{NH}_{3}\right)$. The hematological measurements were performed with a BC-2800 VET semi-automatic hematology analyzer (Mindray, Shenzhen, China), while the biochemical measurements were performed with a BS-120 chemistry analyzer (Mindray, Shenzhen, China).

Statistica 12 (StatSoft, Inc., USA) was used to perform the statistical analyses of the data. The homogeneity of variance was tested with Levene's test. The statistical significance of the growth and condition data was checked with single factor analysis of variance (ANOVA) with repeated measurements. If statistical significance occurred, further analysis was performed with Tukey's test. Differences were considered significant at $\mathrm{P} \leq 0.05$. However, with hematological and biochemical indexes, statistical significance was checked with the Mann-Whitney U test. Differences were statistically significant at $\mathrm{P} \leq 0.05$.

PIT tag retention (42d) in European perch was $100 \%$ (Table 1 ). These values were similar to those obtained, for example, with pikeperch, Sander lucioperca (L.) of a similar size (Hopko et al. 2010, Zakęś and Hopko 2013). The results confirm that the tagging technique is suitable for ichthyological studies and work (Gibbons and Andrews 2004).

The PIT tags were not noted to impact the growth, condition, or feed conversion ratio (FCR) of perch $(\mathrm{P}>0.05$; Table 1$)$. This procedure was not noted to have had a negative impact at any time during the 42 days of observations following PIT implantation. Juvenile pikeperch (BW approximately $80 \mathrm{~g}$, SL approximately $19 \mathrm{~cm}$ ) also exhibited no negative impact from PIT tagging (Hopko et al. 2010), which was done either intraperitoneally or intramuscularly. The implantation method also had no significant impact on the indexes studied in the pikeperch. However, in other studies that examined the effects of PIT tag cheek implantation method in two size groups of pikeperch (BW approximately $60 \mathrm{~g}$, SL approximately $18 \mathrm{~cm}$ and BW approximately $100 \mathrm{~g}$, SL approximately $21 \mathrm{~cm}$ ), temporary decreases in DGR and SGR and increased FCR values were noted in the group of smaller fish for up to 14 days after tagging (Zakęś and Hopko 2013). However, 28 days after tagging, the differences between the tagged and control fish were negligible. The phenomenon of decreased growth rates in PIT tagged individuals are also noted in the first weeks after tagging in perch, 
Table 1

Growth, condition, survival, and PIT tag retention of juvenile European perch (group PIT - tagged fish, group C - untagged fish) in subsequent stages of rearing ( $\mathrm{d} 0$ - fish tagging day, d1, d4, d7, d14, d28, d42, respectively $1,4,7,14,28$, and 42 days after tagging/day of rearing) (mean values $( \pm S D) ; n=6$ )

\begin{tabular}{|c|c|c|}
\hline Parametr / day of rearing & Group PIT & Group C \\
\hline \multicolumn{3}{|l|}{ Body length - SL (cm) } \\
\hline d0 & $15.95( \pm 0.18)$ & $15.81( \pm 0.20)$ \\
\hline $\mathrm{d} 42$ & $17.18( \pm 0.30)$ & $17.09( \pm 0.13)$ \\
\hline \multicolumn{3}{|l|}{ Body weight - BW (g) } \\
\hline d0 & $78.86( \pm 3.16)$ & $75.96( \pm 2.03)$ \\
\hline $\mathrm{d} 7$ & $81.52( \pm 3.87)$ & $79.15( \pm 1.98)$ \\
\hline $\mathrm{d} 14$ & $84.79( \pm 4.23)$ & $82.59( \pm 2.53)$ \\
\hline $\mathrm{d} 21$ & $87.69( \pm 4.74)$ & $86.38( \pm 2.08)$ \\
\hline d28 & $90.48( \pm 5.54)$ & $89.62( \pm 2.69)$ \\
\hline d35 & $93.91( \pm 5.65)$ & $92.72( \pm 3.37)$ \\
\hline $\mathrm{d} 42$ & $98.11( \pm 6.29)$ & $95.48( \pm 3.46)$ \\
\hline \multicolumn{3}{|c|}{ Daily growth rate - DGR $\left(\mathrm{g} \mathrm{d}^{-1}\right)$} \\
\hline $\mathrm{d} 0-\mathrm{d} 7$ & $0.38( \pm 0.16)$ & $0.45( \pm 0.18)$ \\
\hline d7-d14 & $0.47( \pm 0.08)$ & $0.49( \pm 0.13)$ \\
\hline $\mathrm{d} 14-\mathrm{d} 21$ & $0.42( \pm 0.14)$ & $0.54( \pm 0.16)$ \\
\hline $\mathrm{d} 21-\mathrm{d} 28$ & $0.40( \pm 0.14)$ & $0.46( \pm 0.20)$ \\
\hline $\mathrm{d} 28-\mathrm{d} 35$ & $0.49( \pm 0.04)$ & $0.44( \pm 0.21)$ \\
\hline $\mathrm{d} 35-\mathrm{d} 42$ & $0.60( \pm 0.23)$ & $0.39( \pm 0.17)$ \\
\hline $\mathrm{d} 0-\mathrm{d} 42$ & $0.46( \pm 0.08)$ & $0.46( \pm 0.10)$ \\
\hline \multicolumn{3}{|c|}{ Specific growth rate - SGR $\left(\% \mathrm{~d}^{-1}\right)$} \\
\hline $\mathrm{d} 0-\mathrm{d} 7$ & $0.47( \pm 0.18)$ & $0.59( \pm 0.23)$ \\
\hline d7-d14 & $0.56( \pm 0.07)$ & $0.61( \pm 0.15)$ \\
\hline $\mathrm{d} 14-\mathrm{d} 21$ & $0.48( \pm 0.15)$ & $0.64( \pm 0.20)$ \\
\hline $\mathrm{d} 21-\mathrm{d} 28$ & $0.44( \pm 0.14)$ & $0.52( \pm 0.22)$ \\
\hline $\mathrm{d} 28-\mathrm{d} 35$ & $0.53( \pm 0.04)$ & $0.48( \pm 0.22)$ \\
\hline $\mathrm{d} 35-\mathrm{d} 42$ & $0.62( \pm 0.23)$ & $0.42( \pm 0.18)$ \\
\hline $\mathrm{d} 0-\mathrm{d} 42$ & $0.52( \pm 0.07)$ & $0.54( \pm 0.11)$ \\
\hline \multicolumn{3}{|l|}{ Condition coefficient F (-) } \\
\hline d0 & $1.94( \pm 0.06)$ & $1.92( \pm 0.03)$ \\
\hline $\mathrm{d} 7$ & $1.92( \pm 0.05)$ & $1.91( \pm 0.03)$ \\
\hline d14 & $1.94( \pm 0.06)$ & $1.92( \pm 0.06)$ \\
\hline $\mathrm{d} 21$ & $1.85( \pm 0.10)$ & $1.89( \pm 0.09)$ \\
\hline $\mathrm{d} 28$ & $1.90( \pm 0.06)$ & $1.92( \pm 0.04)$ \\
\hline d35 & $1.91( \pm 0.07)$ & $1.91( \pm 0.05)$ \\
\hline $\mathrm{d} 42$ & $1.93( \pm 0.07)$ & $1.91( \pm 0.04)$ \\
\hline \multicolumn{3}{|c|}{ Feed conversion ratio - FCR (-) } \\
\hline $\mathrm{d} 0-\mathrm{d} 7$ & $3.71( \pm 2.65)$ & $3.07( \pm 2.44)$ \\
\hline d7-d14 & $2.69( \pm 0.45)$ & $2.55( \pm 0.67)$ \\
\hline $\mathrm{d} 14-\mathrm{d} 21$ & $3.44( \pm 1.45)$ & $2.45( \pm 0.64)$ \\
\hline $\mathrm{d} 21-\mathrm{d} 28$ & $3.92( \pm 2.16)$ & $3.29( \pm 1.42)$ \\
\hline d28-d35 & $2.78( \pm 0.18)$ & $3.96( \pm 2.58)$ \\
\hline $\mathrm{d} 35-\mathrm{d} 42$ & $2.89( \pm 0.88)$ & $3.99( \pm 1.72)$ \\
\hline $\mathrm{d} 0-\mathrm{d} 42$ & $2.94( \pm 0.47)$ & $2.80( \pm 0.65)$ \\
\hline \multicolumn{3}{|l|}{ Survival (\%) } \\
\hline $\mathrm{d} 0-\mathrm{d} 7$ & 100 & 100 \\
\hline d7-d14 & 100 & 100 \\
\hline $\mathrm{d} 14-\mathrm{d} 21$ & 100 & 100 \\
\hline $\mathrm{d} 21-\mathrm{d} 28$ & 100 & 100 \\
\hline d28-d35 & 100 & 100 \\
\hline d35-d42 & $97( \pm 0.07)$ & 100 \\
\hline $\mathrm{d} 0-\mathrm{d} 42$ & $97( \pm 0.07)$ & 100 \\
\hline \multicolumn{3}{|l|}{ Tag retention (\%) } \\
\hline $\mathrm{d} 0-\mathrm{d} 42$ & 100 & - \\
\hline
\end{tabular}

Details in Material and methods section. No significant differences were noted among groups $(\mathrm{P}>0.05)$ 
but in fish that are significantly smaller (BW approximately 5 g) (Baras et al. 2000). In these studies, the decreased SGR values were only noted 7 days after PIT implantation. In subsequent weeks, the differences between the SGR values, calculated for the tagged perch and the fish from the control group were insignificant. It is noteworthy that the phenomenon of short-term decreases in growth rate are mainly seen in younger fish with lower body weights $<10 \mathrm{~g}$. Such observations in other Perciformes are reported by Navarro et al. (2006) in gilt-head bream, Sparus auratus L. and by Soula et al. (2012) in red porgy, Pagrus pagrus (L.). This type of reaction is generally not observed in response to PIT tagging among larger fish (BW $>50 \mathrm{~g}$ ) such as those in the present study.

Tagging Perciformes with BW $<10 \mathrm{~g}$ with standard PIT tags (approximately $12 \mathrm{~mm}$ in length and $2 \mathrm{~mm}$ in diameter), and especially individuals with $\mathrm{BW}<6 \mathrm{~g}$, can be quite an invasive procedure that leads to higher mortality, especially in the first 7-14 days following manipulation (Baras et al. 2000, Navarro et al. 2006, Soula et al. 2012). In larger fish, for example in pikeperch of a BW > $50 \mathrm{~g}$, mortality is not observed to be a side effect of PIT tagging (Hopko et al. 2010, Zakęś and Hopko 2013). The fish mortality noted in the present study occurred in the last week of observations (d35-d42), and it should be associated with the rearing procedures performed and not with PIT implantation itself (Table 1).

According to the knowledge of the authors, the impact of PIT tagging has not, to date, been assessed in terms of its impact on the physiological state of fish. The study conducted on perch for 42 days following tagging with PIT indicated that this procedure did not have a significant impact on the hematological biochemical

Table 2

Hematological indexes of juvenile European perch tagged with PIT (group PIT) and control group fish (group C) (mean values ( \pm $\mathrm{SD}), \mathrm{n}=35$ )

\begin{tabular}{llll}
\hline \hline Parameter & Unit & Group PIT & Group C \\
\hline \hline WBC & $10^{3} \mu l^{-1}$ & $126.96( \pm 15.49)$ & $120.99( \pm 11.92)$ \\
RBC & $10^{6} \mu l^{-1}$ & $1.63( \pm 0.18)$ & $1.56( \pm 0.14)$ \\
HGB & $\mathrm{g} \mathrm{l}^{-1}$ & $47.16( \pm 7.13)$ & $47.30( \pm 6.99)$ \\
HCT & $\%$ & $23.65( \pm 3.04)$ & $23.09( \pm 2.64)$ \\
MCV & $\mathrm{Fl}$ & $144.98( \pm 9.26)$ & $148.11( \pm 9.28)$ \\
MCH & $\mathrm{Pg}$ & $28.78( \pm 2.90)^{\mathrm{a}}$ & $30.18( \pm 3.22)^{\mathrm{b}}$ \\
MCHC & $\mathrm{g} \mathrm{l}^{-1}$ & $198.45( \pm 10.08)$ & $203.80( \pm 14.73)$ \\
PLT & $10^{3} \mu \mathrm{l}^{-1}$ & $22.9( \pm 6.28)$ & $19.8( \pm 5.22)$ \\
\hline \hline
\end{tabular}

Details in Material and methods section. Groups with different letter indexes differ statistically significantly $(\mathrm{P} \leq 0.05)$

Table 3

Biochemical indexes of the blood plasma of juvenile European perch tagged with PIT (group PIT) and fish from the control group (group C) (mean values $( \pm \mathrm{SD}), \mathrm{n}=35$ )

\begin{tabular}{llll}
\hline \hline Parameter & Unit & Group PIT & Group C \\
\hline \hline CREA & $\mathrm{mg} \mathrm{dl}^{-1}$ & $0.16( \pm 0.10)$ & $0.16( \pm 0.14)$ \\
TP & $\mathrm{g} \mathrm{dl}^{-1}$ & $4.23( \pm 0.59)$ & $4.08( \pm 0.67)$ \\
Bil-T & $\mathrm{mg} \mathrm{dl}^{-1}$ & $0.18( \pm 0.09)$ & $0.19( \pm 0.11)$ \\
ALT & $\mathrm{U} \mathrm{l}^{-1}$ & $32.19( \pm 35.52)$ & $36.51( \pm 45.09)$ \\
ALP & $\mathrm{U} \mathrm{l}^{-1}$ & $40.19( \pm 14.77)$ & $43.46( \pm 18.25)$ \\
$\mathrm{Ca}$ & $\mathrm{mg} \mathrm{dl}^{-1}$ & $12.36( \pm 1.24)$ & $12.37( \pm 0.93)$ \\
$\mathrm{ALB}$ & $\mathrm{g} \mathrm{dl}^{-1}$ & $1.53( \pm 0.20)$ & $1.50( \pm 0.19)$ \\
$\mathrm{GLOB}$ & $\mathrm{g} \mathrm{dl}^{-1}$ & $2.70( \pm 0.42)$ & $2.66( \pm 0.42)$ \\
$\mathrm{GLU}$ & $\mathrm{mg} \mathrm{dl}^{-1}$ & $137.37( \pm 58.31)$ & $112.17( \pm 47.37)$ \\
$\mathrm{Mg}$ & $\mathrm{mg} \mathrm{dl}^{-1}$ & $2.53( \pm 0.29)$ & $2.41( \pm 0.24)$ \\
$\mathrm{NH}$ & $\mu \mathrm{g} \mathrm{dl}^{-1}$ & $484.78( \pm 113.46)$ & $465.70( \pm 119.88)$ \\
\hline \hline
\end{tabular}

Details in Material and methods section. No significant differences were noted among groups $(\mathrm{P}>0.05)$ 
blood indexes analyzed (Tables 2 and 3). Only in the case of mean corpuscular hemoglobin $(\mathrm{MCH})$ was the value in tagged fish lower than that noted in the control group ( $\mathrm{P} \leq 0.05$; Table 3$)$. The lower $\mathrm{MCH}$ value could indicate, for example, anemia associated with iron deficiency or it could be caused by a disease (Sebastiăo et al. 2011). No norm that would indicate a healthy individual exists for this index in perch. The difference among the groups was, on average, $1.40 \mathrm{pg}$ (28.78 vs. 30.18) (Table 3). This was lower than the standard deviation, so the MCH value for the fish tagged with PIT was probably within normal limits. The data available indicate that individual variability in $\mathrm{MCH}$ value for a given species can be considerable, and, for example, in Cichlasoma dimerus (Heckel), a Perciformes species, it ranges from 14.51 to $40.59 \mathrm{pg}$ (Vázquez and Guerrero 2007). Additionally, as previously mentioned, the other hematological index values noted in perch in comparable groups were similar (Table 3).

In summation, intramuscular tagging of juvenile perch with PIT tags did not impact their condition or physiological state. Hematological and biochemical blood parameters are a valuable tool for assessing the physiological state of fish subjected to this type of procedure. However, drawing more conclusive conclusions will require expanding the resources of this type of data.

Acknowledgments. The study was conducted within the framework of the research programmes of the Inland Fisheries Institute (No. S-028) and the University of Warmia and Mazury (No.0804-0809).

Author contributions. Z.Z. designed the research; M.R., E.Z., K.D.-Z. and Z.Z. performed the research; Z.Z., M.R., E.Z., K.D-Z analyzed the data; Z.Z., M.R., K.D.-Z. wrote the paper.

\section{References}

Akrami R., Gharaei A., Karami R. 2013 - Age and sex specific variation in hematological and serum biochemical parameters of beluga (Huso huso Linnaeus, 1758) - Int. J. Aquat. Biol. 1(3): 132-137.
Ballard G., Ainley D., Ribic C., Barton K.R. 2001 - Effect of instrument attachment and other factors on foraging trip duration and nesting success of a délie penguins - The Condor 103: 481-490.

Baras E., Malbrouck C., Houbart M., Kestemont P., Mélard C. 2000 - The effect of PIT tags on growth and physiology of age-0 cultured Eurasian perch Perca fluviatilis of variable size - Aquaculture 185: 159-173.

Brady M.J., Risch T.S., Dobson F.S. 2000 - Availability of nest sites does not limit population size of southern flying squirrels - Can. J. Zool. 78: 1144-1149.

Brinn R.P., Marcon J.L., Gomes D.M., Abreu L.C., Baldisseroto B. 2012 - Stress responses of the endemic freshwater cururu stingray (Potamotrygon cf. histrix) during transportation in the Amazon region of the Rio Negro - Comp. Biochem. Physiol. A 162: 139-145.

Çelik E. 2004 - Blood chemistry (electrolytes, lipoproteins and enzymes) values of black scorpion fish (Scorpaena porcus Linneaus 1758) in the Dardanelles - Turk. J. Biol. 4: 716-719.

Folmar L.C. 1993 - Effects of chemical contaminants on blood chemistry of teleost fish: a bibliography and synopsis of selected effects - Environ. Toxicol. Chem. 12: 337-375.

Gibbons J.F., Andrews K.M. 2004 - PIT tagging: simple technology at its best - BioScience 54: 447-454.

Hopko M., Zakęś Z., Kowalska A., Partyka K. 2010 - Impact of intraperitoneal and intramuscular PIT tags on survival, growth, and tag retention in juvenile pikeperch, Sander lucioperca (L.) - Arch. Pol. Fish. 18: 85-92.

Mills M., Hudson C.J., Berna H.J. 1995 - Spatial ecology and movements of the brown water snake (Nerodia taxispilota) - Herpetologica 51: 412-423.

Navarro A., Oliva V., Zamorano M.J., Ginés R., Izquierdo M.S., Astorga N., Afonso J.M. 2006 - Evaluation of PIT system as a method to tag fingerlings of gilthead seabream (Sparus auratus L.): effects on growth, mortality and tag loss - Aquaculture 257: 309-315.

Pengilly D., Watson L.J. 1994 - Automated detection of internally injected tags in red king crabs at crab processing facilities - Fish. Res. 19: 293-300.

Perret N., Joly P. 2002 - Impacts of tattooing and PIT-tagging on survival and fecundity in the Alpine newt (Triturus alpestris) - Herpetologica 58: 131-138.

Policar T., Samarin A.M., Mélard C. 2015 - Culture methods of Eurasian perch during ongrowing - In: Biology and culture of percid fishes - principles and practices (Eds) P. Kestemont, K. Dabrowski, R.C. Summerfelt, Springer, Netherlands: 417-435.

Prentice E.F., Flagg T.A., McCutcheon C.S. 1990 - Feasibility of using implantable passive integrated transponder (PIT) tags in salmonids - Am. Fish. Soc. Symp. 7: 317-332. 
Sebastiăo F.A., Nomura D., Sakabe R., Pilarski F. 2011 Hematology and productive performance of Nile tilapia (Orechromis niloticus) naturally infected with Flavobacterium columnare - Braz. J. Microbiol. 42: 282-289.

Skalski J.R., Buchanan R.A., Griswold J. 2009 - Review of marking methods and release-recapture designs for estimating the survival of very small fish: examples from the assessment of salmonid fry survival - Rev. Fish. Sci. 17: 391-401.

Soula M., Navarro A., Hildebrandt S., Zamorano M.J., Roo J., Hernández-Cruz C.M., Afonso J.M. 2012 - Evaluation of VIE (Visible Implant Elastomer) and PIT (Passive Integrated Transponder) physical tagging systems for the identification of red porgy fingerlings (Pagrus pagrus) Aquacult. Int. 20: 571-583.
Val A.L., Affonso E.G., Dealmeidaval V.M.F. 1992 - Adaptive features of Amazon fishes - blood characteristics of curimata (Prochilodus cf nigricans, Osteichthyes) Physiol. Zool. 65: 832-843.

Vázquez G.R., Guerrero G.A. 2007 - Characterization of blood cells and hematological parameters in Cichlasoma dimerus (Teleostei, Perciformes) - Tissue Cell 39: 151-160.

Zakęś Z., Hopko M. 2013 - Tagging juvenile pikeperch (Sander lucioperca (L.)) in the cheek with Passive Integrated Transponders (PIT) - impact on rearing indexes and tag retention - Arch. Pol. Fish. 21: 243-248.

Zutshi B., Raghu Prasad S.G., Nagaraja R. 2010 - Alteration in hematology of Labeo rohita under stress of pollution from Lakes of Bangalore, Karnataka, India - Environ. Monit. Assess. 168: 11-19. 